\title{
TRENDS IN LIBRARY SCIENCE RESEARCH TOPICS DURING THE PERIOD 2016-2019
}

\author{
Muh. Quraisy Mathar* \& Ayu Trysnawati*
}

*Library Science Department, Universitas Islam Negeri Alauddin Makassar

Email:aiscorner76@gmail.com,ayu.trysnawati@uin-alauddin.ac.id

(Submitted: 22-01-2021, Revised: 20-05-2021, Accepted: 08-06-2021)

DOI: $10.24252 / \mathrm{v} 9 \mathrm{i} 1 \mathrm{a} 9$

\begin{abstract}
ABSTRAK: Sejak berdiri tahun 1999 lalu, telah ada ratusan penelitian yang dihasilkan oleh alumni Jurusan Ilmu Perpustakaan UIN Alauddin Makassar. Kajian bibliometrika ini bertujuan untuk melihat tren topik penelitian mahasiswa Jurusan Ilmu Perpustakaan periode 2016-2019 dan juga melihat jenis literatur yang digunakan sebagai rujukan dalam penelitian. Data penelitian diperoleh dari 363 skripsi versi cetak yang diperoleh di Perpustakaan Fakultas Adab dan Humaniora dan Database Slims di Perpustakaan Fakultas Adab dan Humaniora periode 2016-2019. Hasil penelitian menunjukkan bahwa terdapat 19 kategori topik penelitian yang telah dihasilkan tahun 2016-2019. Ada 5 tren topik penelitian yang paling sering dikaji yaitu bahan pustaka $22,09 \%$, selanjutnya topik pustakawan $12.14 \%$, topik layanan dan pemustaka $8,25 \%$ dan topik teknologi perpustakaan $8.01 \%$. penelitian ini dapat berimplikasi pada perumusan formula baru tentang arah dan tujuan topik penelitian pada bidang Ilmu Perpustakaan ke depannya.
\end{abstract}

Kata kunci: Ilmu perpustakaan; bibliometrika

ABSTRACT: Since its establishment in 1999, the Library Science Department of UIN Alauddin Makassar have been producing hundreds of researches in the field written by its alumni. This bibliometric study described the trend of research topics written by the undergraduate library science students in the department during the period 2016-109. It also described the various types of documents cited as references in the researches. 336 undergraduate theses were obtained from the faculty library database. It is found that there were 19 categories of research topics that had written during the period. There were 5 trends in research topics that are most frequently studied, namely Library Collections 22,09 \%, Librarians 12,14 \%, Library Services and Librarian 8,25 \%, and Library Technology 8,01\%. This research can have implications for the design of new formulas regarding the direction and objectives of research in the field of library science in the future.

Keywords: Library science; bibliometrics

\section{INTRODUCTION}

The development of science can be measured through the number of publications related to a field of science, for example, the numbers of the results of field research and the results of literature studies. One form of research in the university is a thesis. These collections of theses can be used to determine the development of certain sciences. That is why every university requires its students and lecturers to remain active in publishing their writings. According to Sulistyo-Basuki (2009), the field of library science can anticipate the information explosion by developing it into a science that can be taught to the public. This department of library science 
is used as a forum to distribute and teach knowledge about libraries at various universities around the world.

The Department of Library Science, Faculty of Adab and Humanities, UIN Alauddin Makassar, which was officially opened in 1999, is still actively educating its undergraduate students. This department offered a Bachelor of Library Science and has graduated a hundred scholars in the field. The alumni have also worked in various institutions or information centers and various types of libraries, like in school libraries, academic libraries, public libraries, and special libraries. The department will continue to make various efforts so that the alumni might have competencies that suit their needs and are ready to work well.

One way to know the development of scientific disciplines is to measure the statistics of their publications, or what is commonly referred to as bibliometric studies. The department of library science at UIN Alauddin Makassar is an interesting study to know about the development of its publications. By mapping and analyzing thesis topics studied by the alumni, it can find out several things, namely:1) the most dominant topic written by the students, 2) interests and tendencies of students regarding the field of library science, 3 ) the direction of the development of library science. Thus, The Department of Library Science can revise the curriculum for some or all courses offered or determine a better research direction in the future.

Writing a thesis is always related to the activity of citing other people's writings, it is an inseparable part of scientific writing activities (Hasugian, 2005). Bibliometrics can be used as citation analysis. This approach is one of the studies of library and information science. Through this approach, it can compare the types of forms, and the latest documents cited in the thesis bibliography. Besides that, Glanzel in Pattah (2013) stated that the object of bibliometric study can be done by analyzing types of scientific literature, such as books, monographs, research reports, theses, dissertations, and journal articles. This study will analyze the thesis of the Department of Library Science in UIN Alauddin Makassar about the trend of thesis topics and bibliometric studies. The study aims to determine; 1) the trend of thesis research topics in the department during the period 2016-2019,2) The theses majors in the department in terms of the types of literature and literary language.

\section{PREVIOUS FINDINGS}

In his paper, Pritchard (1969) defines statistical bibliometrics as the application of mathematics and statistical methods to books and other media of communication. According to Bremholm (2015), bibliometrics is the study of patterns in the publication and use of documents, while bibliometric laws define predictable relationships in those patterns. Research on the use of bibliometric studies as a method of evaluation and study in the library and information science was carried out by Pattah (2013) which states that bibliometric studies are conducted to understand information needs, usage patterns, and usage behavior, especially researchers in the field of library and information in the development of information organizations. One of the studies in the field of bibliometrics is citation which is very important to see citing documents or cited documents. With this analysis, various studies can be carried out that will provide benefits for research policies, institutions, and universities. Other fields of bibliometrics can also be used to measure the degree of author collaboration, for example, a study conducted Mathar (2014). This research showed that the level of authors' collaboration on articles related to digital literacy published during 1997-2013 was 0.62 or $62 \%$, indicating that more than half of the 661 articles were multi-authored papers. In addition, the American continent proportionately contributes in discussing the topic of digital literacy.

Co-word analysis and citation analysis approaches are also part of bibliometric. Co-word analysis is used to see trends in research topics grouped by keywords and based on Hawkins' taxonomy (Dwiyantoro \& Junandi, 2019). For example, a study conducted by Mustafa (2008) related to the frequency of occurrence of words in a document (words occurrence or word 
frequency). Zipf's law regarding the frequency of occurrence of words in a document as a measure of indexing. As for research related to research topic trends in the field of library and information, among others, carried out by Markey (2004), Chen \& Larsen (2014), Park \& Song (2013), Liu \& Yang (2019), and Ma \& Lund (2021).

The studies mentioned above show that bibliometric analysis is a study of the pattern of publication of documents or disciplines where a quantitative approach is used for the field of science that includes various aspects of the subject, author, citation, title, and others.

\section{RESEARCH METHODOLOGY}

The data were obtained from all thesis titles that have been written in the Department of Library Science, namely 336 theses during the period 2016-2019. The data is then grouped and displayed using Ms. Excel. From this subject analysis activity, keywords will be obtained to facilitate the process of bibliometric analysis of co-words analysis, as well as determining subject clusters. In addition to using co-words analysis, the researchers also use citation analysis. According to Sugiyono (2008), this method is a quantitative method used to find the structure of knowledge by grouping keywords from the scientific literature.

\section{RESULTS AND FINDINGS}

\section{The Numbers of Undergraduate Theses}

From 2016 to 2019, the Department of Library Science in UIN Alauddin Makassar had produced as many as 336 undergraduate theses, as shown in the table below.

\begin{tabular}{ccc} 
& Table 1. Numbers of theses \\
\hline No & Year & Total \\
\hline 1 & 2016 & 74 \\
2 & 2017 & 140 \\
3 & 2018 & 79 \\
4 & 2019 & 43 \\
& Total & 336 \\
\hline
\end{tabular}

Meanwhile, from all undergraduate theses, it is then categorized into 19 research topics as shown below.

Tabel 2. Research topics

\begin{tabular}{clcc}
\hline No & \multicolumn{1}{c}{ Topics } & Total & $\%$ \\
\hline 1 & Library collections & 91 & 22,09 \\
2 & Librarian & 50 & 12,14 \\
3 & Library service & 34 & 8,25 \\
4 & Library users & 34 & 8,25 \\
5 & Technology in library & 33 & 8,01 \\
6 & Literation & 21 & 5,10 \\
7 & Library management & 20 & 4,85 \\
8 & Library promotion & 14 & 3,40 \\
9 & Library design & 8 & 1,94 \\
10 & Library organization & 5 & 1,21 \\
11 & Digital library & 5 & 1,21 \\
12 & Users' education & 4 & 0,97 \\
13 & Classification & 4 & 0,97 \\
14 & Library facility & 3 & 0,73 \\
15 & Non-print library collection & 3 & 0,73
\end{tabular}




\begin{tabular}{llcc}
16 & Regulation & 2 & 0,49 \\
17 & Reading interest & 2 & 0,49 \\
18 & Library & 2 & 0,49 \\
19 & Archive & 1 & 0,24 \\
& \multicolumn{1}{c}{ Total } & 336 & $100 \%$ \\
\hline
\end{tabular}

\section{The types of documents cited}

There are various types of documents that are used by students as references in writing their theses as listed below.

Table 3. Document types

\begin{tabular}{clcc}
\hline No & \multicolumn{1}{c}{ Document Types } & Total & $\%$ \\
\hline 1 & Book & 5766 & 81 \\
2 & Journal & 454 & 6 \\
3 & Thesis & 290 & 4 \\
4 & Internet & 277 & 4 \\
5 & Master Thesis & 183 & 3 \\
6 & Grey Literature & 74 & 1 \\
7 & Dictionary & 65 & 1 \\
8 & Proceeding & 5 & 0 \\
& Total & 7114 & $100 \%$ \\
\hline
\end{tabular}

\section{The languages used}

Of the thousands of readings listed in the references section, there were only 2 languages of those readings, as shown below.

Tabel 4. Languages used

\begin{tabular}{|c|c|c|c|}
\hline No & Languages & Total & $\%$ \\
\hline 1 & Indonesian & 6561 & 92 \\
\hline 2 & English & 533 & 8 \\
\hline & Total & 7094 & $100 \%$ \\
\hline
\end{tabular}

\section{CONCLUSION}

The department of library science of UIN Alauddin Makassar had produced hundreds of undergraduate theses during the period 2016-2019. There are 336 theses in which categorized into 19 research topics. From these categories, 5 topics are most frequently studied which are Library Collections, Librarians, Library Services, Library Users, and Library Technology. While the types of documents cited as references in the theses are books. In addition, dictionaries, undergraduate theses, theses, grey literature, and proceedings are also the types of the document cited. Reading materials in the Indonesian language is still dominant. However, some theses refer to English reading materials. This research has implications for the formulation of new directions and objectives of research topics in the field of library science. In addition, lecturers can limit or provide students' views in choosing thesis topics that have been frequently studied by students and can direct students who will complete thesis final projects on topics that can be used as thesis research topics so that they can further develop and enrich future of library science. 


\section{REFERENCES}

Pritchard, A. (1969). Statistical Bibliography or Bibliometrics?. Journal of Documentation 25(4):348-349.

Bremholm, T. L. (2015). Author Productivity and Citation Frequency in the Proceedings of the Oklahoma Academy of Science, 1921-2000. Proceedings of the Oklahoma Academy of Science, 84, 53-66.

Chen, C. \& Larsen, R. (2014). Library and information sciences: Trends and research. Springer.

Dwiyantoro, \& Junandi, S. (2019). Tren Topik Penelitian dan Kajian Bibliometrik Prosiding Bidang Ilmu Perpustakaan di Indonesia Periode 2015-2017. Media Pustakawan, 26(3), 199. https://ejournal.perpusnas.go.id/mp/article/view/533/0

Hasugian, J. (2005). Analisis Sitiran Terhadap Disertasi Program Doktor (S-3) Ilmu Kedokteran Sekolah Pascasarjana Universitas Sumatera Utara. Pustaha, 1(2), 1-11-11.

Liu, G. \& Yang, L. (2019). Popular research topics in the recent journal publications of library and information science. The Journal of Academic Librarianship. 45(6), 278-287.

Ma, J. \& Lund, B. (2021). The evolution and shift of research topics and methods in library and information science. JASIST Journal of The Association for Information Science and Technology. 72(8), 1059-1074.

Markey, K. (2004). Current Educational Trends in the Information and Library Science Curriculum. Journal of Education for Library and Information Science. 45(4), 317-339.

Mathar, T. (2014). 1997 To 2013 : a Bibliometric Study. Khizanah Al-Hikmah, 2(2), 149-160. http://journal.uin-alauddin.ac.id/index.php/khizanah-al-hikmah/issue/view/20

Mustafa, B. (2008). Hukum Zipf Mengenai Frekuensi Kata Dalam Dokumen Sebagai Dasar Pengembangan Sistem Pengindeksan Otomatis (Automatic Indexing).

Park, J. H. \& Song, M. (2013). A Study on the Research Trends in Library \& Information Science in Korea using Topic Modeling. Journal of the Korean Society for information Management $30(1)$.

Pattah, S. H. (2013). Pemanfaatan Kajian Bibliometrika sebagai Metode Evaluasi dan Kajian dalam Ilmu Perpustakaan dan Iinformasi. Jurnal Ilmu Perpustakaan \& Informasi KHIZANAH ALHIKMAH, 1(1), 47-57. http://journal.uin-alauddin.ac.id/index.php/khizanah-alhikmah/article/view/25

Sugiyono. (2008). Strategi Nonparametris Untuk Penelitian. Alfabeta.

Sugiyono. (2010). Metode Penelitian Pendidikan: Pendekatan Kuantitatif, Kualitatif dan R\&D. Alfabeta.

Sulistyo-Basuki. (2009). Pengantar Ilmu Perpustakaan. Universitas Terbuka. 